\title{
On the acceleration of land subsidence rate in Semarang City as detected from GPS surveys
}

\author{
Heri Andreas ${ }^{1, *}$, Hasanuddin Zainal Abidin ${ }^{1}$, Irwan Gumilar, Teguh Purnama Sidiq, Dina Anggreni Sarsito ${ }^{1}$ \\ and Dhota Pradipta ${ }^{1}$
}

${ }^{1}$ Geodesy Research Division, Faculty of Earth Science and Technology, Institute of Technology Bandung, Indonesia

\begin{abstract}
Land subsidence is not a new phenomenon for Semarang the capital city of Central Java Province with recent population of about 1.5 million. Some report said the subsidence in Semarang probably is occurring for more than 100 years. Geodetic surveys such as GPS Surveys can detect land subsidence accurately. Land subsidence in Semarang exhibits spatial and temporal variations with the typical average rates of about 3 to $10 \mathrm{~cm} /$ year until recently it seem the acceleration existed in some region of the city. This acceleration will increase the risk of negative consequences from the land subsidence. This paper present and discuss the acceleration of land subsidence in Semarang as detected from GPS Surveys. The surveys have been conducted in 2008, 2009, 2010, 2012, 2016 and 2017. From 2008 to 2012 the subsidence generally follow linier rates while from 2012 to 2017 seem they are accelerating. The northern eastern region of Semarang along the coastal area still exhibits relatively higher rates of subsidence along with acceleration in rates compare to others region. Ground water exploitation is suspected to be the causes of that land subsidence phenomenon in Semarang city
\end{abstract}

\section{Introduction}

Semarang is the capital city of Central Java Province, located in the northern coast of Java Island, Indonesia (see Figure 1). Size area of Semarang is about 37,367 hectares or $374 \mathrm{~km} 2$, with the population of about 1.55 million people in 2010 (BPS [1]). Geographical center of the city are $-6^{\circ} 58^{\prime}$ (latitude) and $+110^{\circ} 25^{\prime}$ (longitude). Topographically, Semarang consists of two major landscapes, namely lowlands and coastal areas in the north and hilly regions in the south. The northern part, comprising the city center, harbor, airport and railway stations, is relatively flat with topographical slopes ranging between $0^{\circ}$ and $2^{\circ}$, and altitude between 0 and $3.5 \mathrm{~m}$. The southern part includes slopes up to $45^{\circ}$ and altitude up to about $350 \mathrm{~m}$ above sea level. The northern part has relatively higher population density and also has more industrial and business areas compared to the southern part. The land use of the southern part consists of residential housing, offices, retail, public use and open space areas.

Land subsidence is not a new phenomenon for Semarang the capital city of Central Java province with recent population of about 1.5 million. Some report said the subsidence in Semarang probably is occurring for more than 100 years. Based on the leveling surveys conducted by the Centre of Environmental Geology (GRDC [2]) from 1999 to 2003 it was found that relatively large subsidence was detected around northern place with the rates ranging from 1 to $17 \mathrm{~cm} /$ year. Results derived from GPS show that land subsidence has spatial and temporal variations. In general, subsidence rates in Semarang have an average rate of about 6 to 7 $\mathrm{cm} /$ year, with maximum rates that can go up to 14-19 $\mathrm{cm} /$ year at certain locations (Kuehn and Murdohardono [3], Lubis et. al [4], Abidin et. al [5]). The estimation based on the PS (Permanent Scatterer) InSAR technique also revealed that the areas close to the shoreline have subsidence rates of more than $8 \mathrm{~cm} /$ year (Murdohardono et al [6], Kuehn et al [7]).

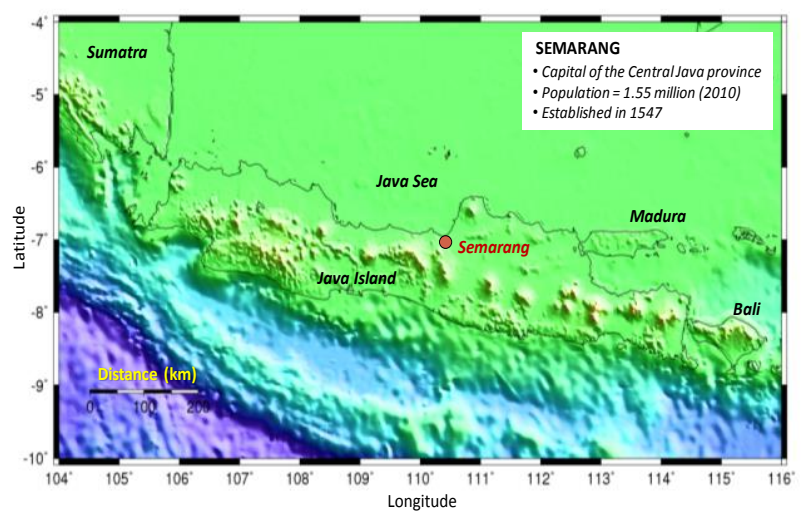

Fig. 1. Map of location of Semarang city, the capital city of Central Java province

If we see geology of Semarang, there are three main lithology, namely, volcanic rock, sedimentary rock, and alluvium deposits. According to Sukhyar [8], the basement of Semarang consists of Tertiary Clay stone of

*Corresponding author: heriandreas49@gmail.com 
the Kalibiuk Formation. Overlying this formation is the Notopuro Formation which consists of Quaternary volcanic material. The two formations crop out in the southern part of the Semarang area. The northern part of Semarang is composed by very young alluvium with high compressibility. According to Barry [9] and Geological Research and Development Centre of Indonesia (GRDC) [2]), the alluvial deposits found in coastal areas of Semarang consist of beach, floodplain, tidal, near-shore, and alluvial fan deposits, as illustrated in Figure 2. Aquifers are found at depths ranging from 30 to $80 \mathrm{~m}$ in this alluvium. The northern part of the Semarang area is covered by Kali Garang deltaic alluvium up to a depth of 80 to $100 \mathrm{~m}$ in the coastal area. Several studies (Van Bemmelen [10], Marfai et.al [11]) have reported that in the period of 1695 to 1991 , the shoreline of Semarang progresses relatively quick toward the sea, namely about $2 \mathrm{~km}$ in 2.5 centuries or about $8 \mathrm{~m} /$ year in average. Therefore it can be expected that a natural consolidation process is still occurring until now, causing also land subsidence in the northern part of Semarang.

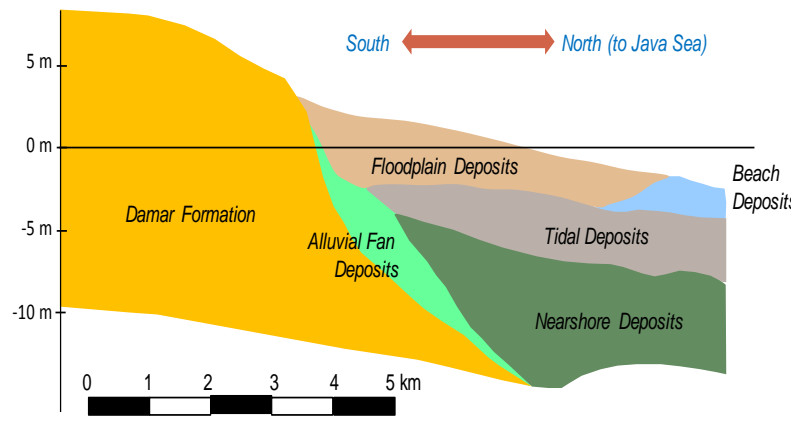

Fig.2. South to North cross section of Quaternary geological section East of Kaliwungu Semarang, after GRDC [2]

In spite of general trend of subsidence around the area of Semarang city, recent GPS surveys indicate the acceleration on its rate. This fact is very interesting especially for identification of the risks from negative impact of subsidence. Acceleration means more risks. So, this paper will present and discuss the acceleration of land subsidence in Semarang as detected from GPS Surveys. Hopefully our finding will be useful for the next steps of dealing with subsidence in the area.

\section{Method}

GPS (Global Positioning System) and InSAR (Interferometric Synthetic Aperture Radar) has been played as remarkable tool for monitoring land subsidence. As for GPS, this technology is best achievement so far for best positioning and mapping with high accuracy can be achieved in the easiest way (Seeber, [12], Abidin, [13-14], Hofmann et. al [15]). In everywhere and in anytime worldwide when signals from the satellites received by the receivers, in these cases the position in 3D or even 4D (like measuring land subsidence) can be determined precisely and even with precision in the order of millimeter.
To measure the land subsidence, the GPS surveys should be conducted repeatedly in each monitoring point in each session with observation to the satellite for about 10-12 hour. One station placed at stable area will be as reference station while others station located at suspected area as monitoring points or station. Figure 3 shows illustration of GPS surveys on monitoring land subsidence. Measurement can be done also continuously over points, but the cost will be relatively high. We even now have new approach of GPS extensometer, the combination of GPS and deep pile monitoring layers of subsidence.

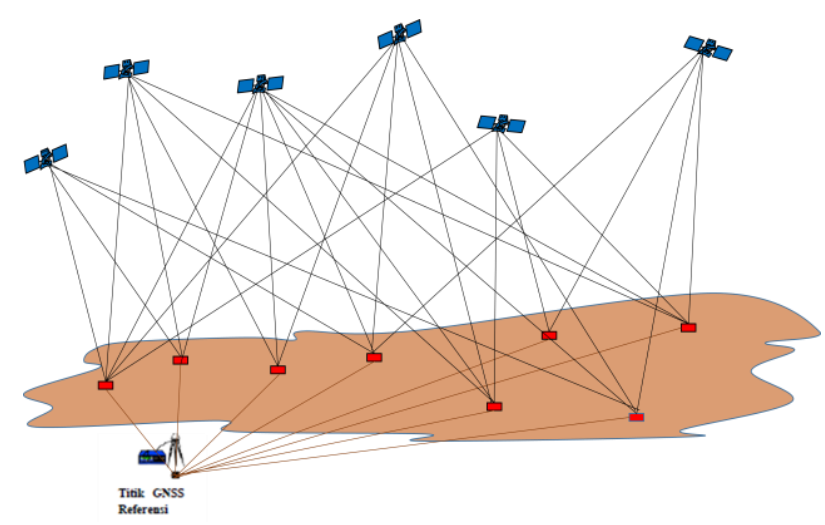

Fig.3. Illustration of GPS surveys for monitoring land subsidence. One point set up in stable area for reference while the others located on suspected area of subsidence

Figure 4 shows location of GPS surveys for monitoring land subsidence in Semarang area. Around 50 stations installed in suspected area of subsidence while the reference point set up at stable are in the southern part of Semarang city. In each point and each session we observed 10 hours. The surveys have been conducted in 2008, 2009, 2010, 2012, 2016 and 2017.

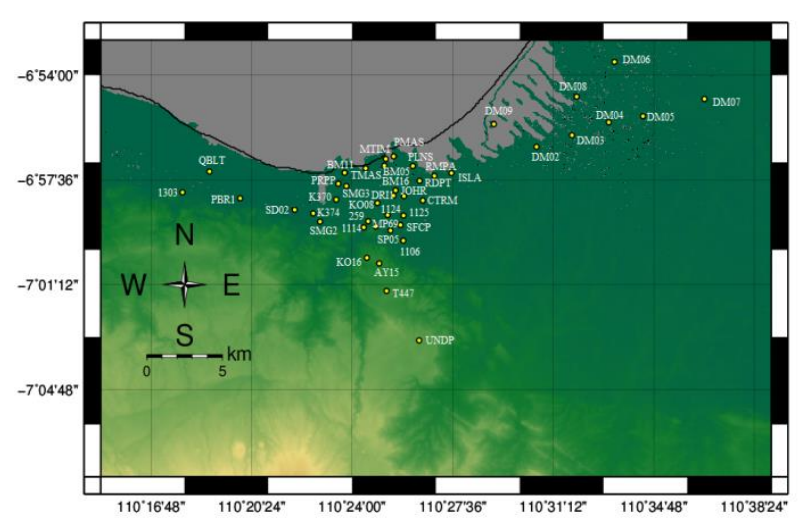

Fig.4. Location of GPS station for monitoring land subsidence in Semarang and the surrounding area.

Figures 5 show several documentations of measurements in the field. We use dual frequency geodetic type receiver Topcon GR3 and GR5 for most of the observations. In the early measurement we use Trimble 4000 SSE. Using the same type of receiver and also antenna type may reduce the error of antenna phase center and any other systematic error due to the device. 


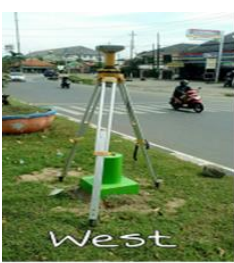

RDPT

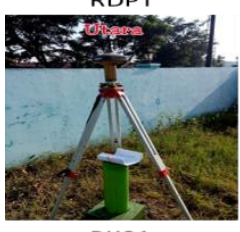

PKO1

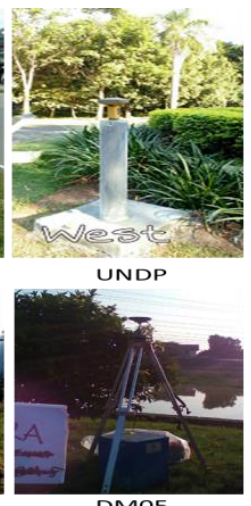

DMO5

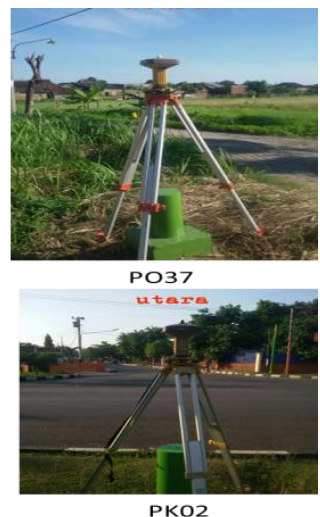

Fig.5. Documentation of GPS land subsidence monitoring point in Semarang and the surrounding area.

Table 1 shows the complete parameters observation strategy in order to monitor land subsidence by using GPS technology. As mentioned above we observe in each session each station for about 10-20 hour with observation rate of 30 second, we collect data from two frequency, we use specific antenna type to respond to the multipath potency, using mask angle 15 degree, etc.

Table 2 shows parameters taking into account for GPS data processing strategy in order to monitor land subsidence by using GPS technology. We use precise ephemeris to improve orbit accuracy, we estimate troposphere, we do linier combination to handle ionosphere biases, etc. Software for data processing is Bernese 5.2 (Beutler [16]). It is a scientific software that is good in handling most error and biases including resolving the phase ambiguity.

Table 1. Parameters observation strategy in order to monitor land subsidence by using GPS technology.

\begin{tabular}{|l|l|}
\hline \multicolumn{2}{|c|}{ Parameters observation strategy } \\
\hline Receiver & Geodetic Type dual frequency \\
\hline Observation rate & 30 seconds \\
\hline Observation length & $8-10$ hour \\
\hline Mask Angle & 15 degree \\
\hline Data collected & Code and Phase \\
\hline Others data & Field condition \\
\hline
\end{tabular}

Table 2. Parameters processing strategy in order to monitor land subsidence by using GPS technology

\begin{tabular}{|l|l|}
\hline \multicolumn{2}{|c|}{ Parameters processing strategy } \\
\hline Orbit & Precise ephemeris \\
\hline Atmospheric biases & $\begin{array}{l}\text { Combination of dual } \\
\text { frequency forionosphere and } \\
\text { estimation for troposphere }\end{array}$ \\
\hline Antenna & Phase center correction \\
\hline Phase ambiguity & QIF strategy \\
\hline $\begin{array}{l}\text { Other biases and } \\
\text { errors }\end{array}$ & Differencing and neglected \\
\hline
\end{tabular}

\section{Results}

Result of GPS data processing in every campaign so far; especially for the vertical component shows the accuracy mostly in several millimeters to maximum only reach 1 centimeter. These results proved the software is capable in reducing significantly the biases and errors on GPS data. Generally only the residual of troposphere effect and the noise on the signal those are still remains. With these accuracies we can confident to see the signal of deformation (e.g. subsidence) even in small value (e.g. several centimeters per year). Simply by comparing vertical position in each campaign in each monitoring point, the subsidence could reveal.

Figure 6 to 10 shows example of result on subsidence in several monitoring points out of 50 monitoring points in the field. From the figures we can see the graph of subsidence since 2008 up to 2016. It is clearly shown the pattern of acceleration of subsidence in almost all of the graphs. In detail, from 2008 to 2012 the subsidence generally follow linier trend while from 2012 to 2017 seem they are accelerating. The magnitude it shelf from 2008 to 2016 vary between 20 centimeter to 1.5 meter.

It is very interesting to analyze on how the subsidence is being accelerated. Something must drive the subsidence to accelerate. We assumed that it might be the anthropogenic causes like groundwater exploitation or natural causes like tectonic and natural compaction. Further on we can understand that the acceleration mean more risk to the impact from the subsidence on the area. We will discuss on the next chapter of all varieties causes of land subsidence in Semarang area. In many cases around the world, the groundwater exploitation plays an important role for land subsidence existence.

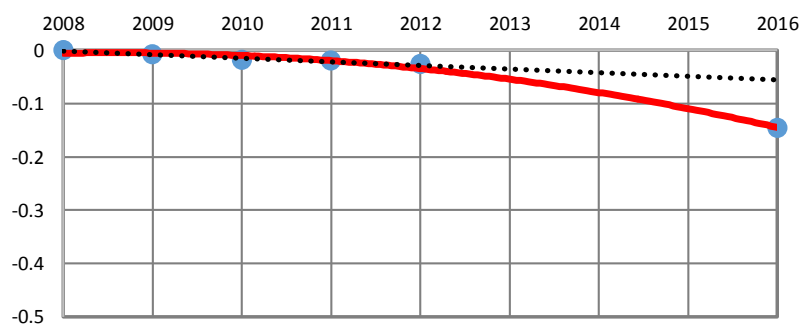

Fig. 6. Graph of land subsidence in station 1303 west northern Semarang from 2008-2016. Y axis shows magnitude in meter

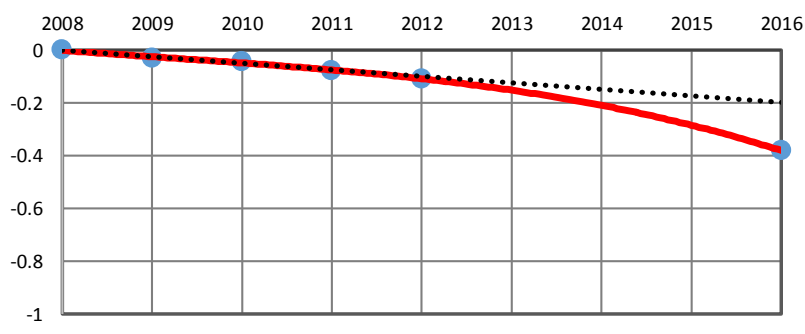

Fig.7. Graph of land subsidence in station QBLT west northern Semarang from 2008-2016. Y axis shows magnitude in meter 


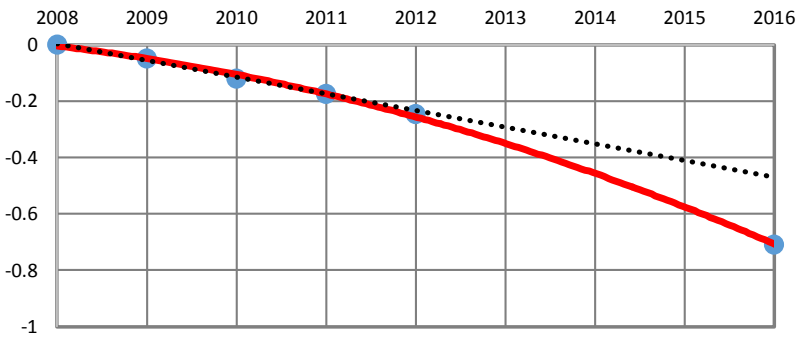

Fig.8. Graph of land subsidence in station BM05 northern Semarang from 2008-2016. Y axis show magnitude in meter

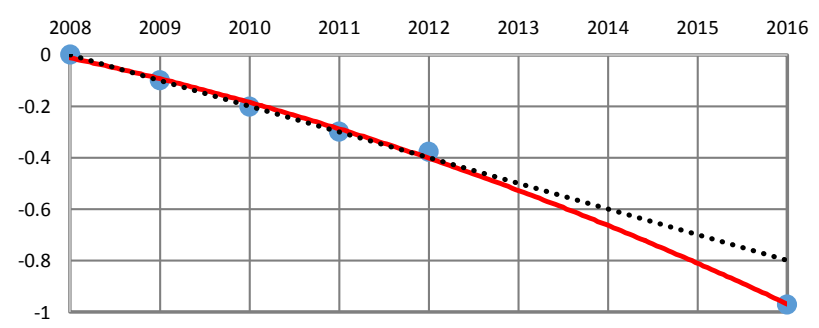

Fig.9. Graph of land subsidence in station RMPA northern eastern Semarang from 2008-2016. Y axis shows magnitude in meter

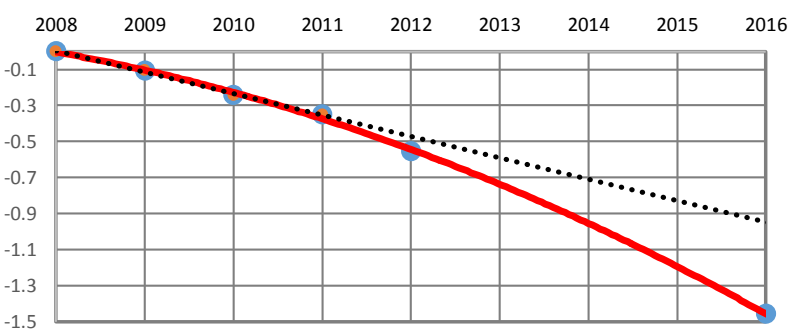

Fig.10. Graph of land subsidence in station SMG5 northern eastern Semarang from 2008-2016. Y axis shows magnitude in meter

Figure 11 shows map of information of subsidence characteristic in each stations over Semarang and the surrounding area. We can see most of the stations in northern eastern Semarang are experiencing acceleration in subsidence rates, meanwhile in central Semarang the subsidence is happening generally in the linear rate. Null subsidence is also recognize in the southern part of Semarang.

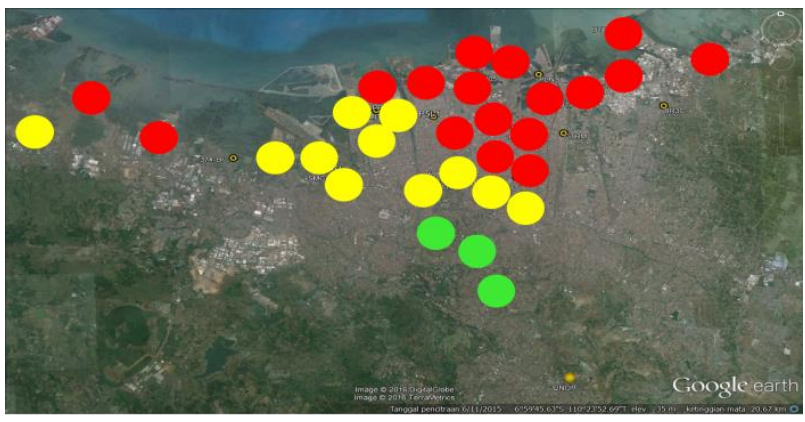

Nul subsidence constant subsidence Acceleration on subsidence

Fig.11. Map of information of subsidence characteristic in each station over Semarang and the surrounding area.

\section{Discussions}

The impact of land subsidence on the coastal area (e.g. in Semarang) can be seen in several forms, such as the wider expansion of (coastal) flooding areas, cracking of buildings and infrastructure and increased inland sea water intrusion. It also badly influences the quality and amenity of the living environment and life (e.g. health and sanitation condition) in the affected areas. The economic losses caused by land subsidence are enormous; since many buildings and infrastructure severely affected by this silent disaster of subsidence. Many houses, public utilities and a large number of populations are also exposed to this silent disaster. The corresponding maintenance cost is increasing every year. The living conditions of the affected population are deteriorating. The quality of their social and economic activity is consequently decreasing as well.

Figure 12 shows coastal flooding documentation in northern eastern part of Semarang city while figure 13 shows time series of high resolution satellite images around Tanjung Mas northern eastern of Semarang city from 2005 up to 2015. From the images we can see one place that is used to be land but now become the sea area. Indeed it is real view of disaster due to the occurring of land subsidence phenomenon.

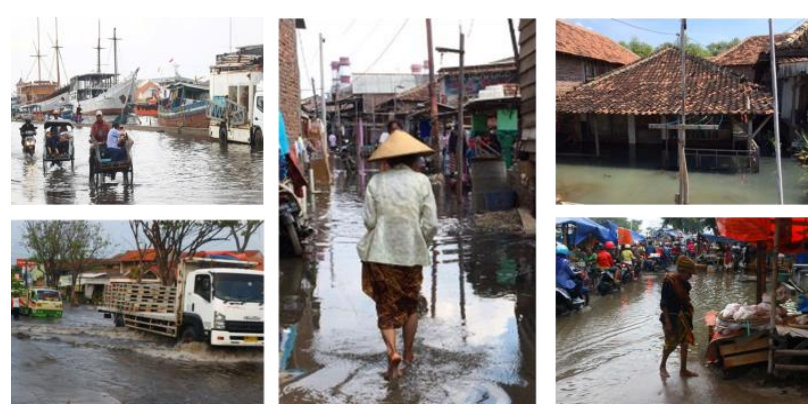

Fig.12. Coastal flooding documentation in northern part of Semarang city due to land subsidence.
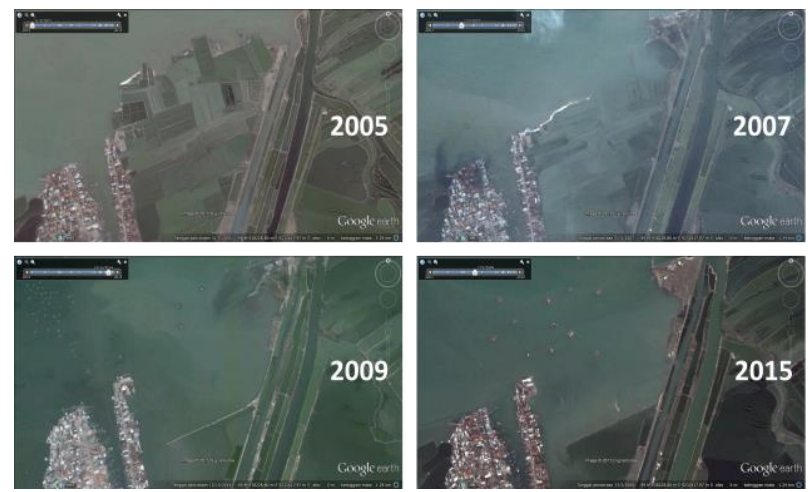

Fig.13.Time series of high resolution satellite images showing land loss to the sea due to land subsidence.

If indeed we have acceleration on the rate of subsidence, it would be mean that more severe disaster may be existed in the area. In this case we need to do better either mitigation or adaptation against the land subsidence. The beginning of the action is by understanding the causes of land subsidence. 


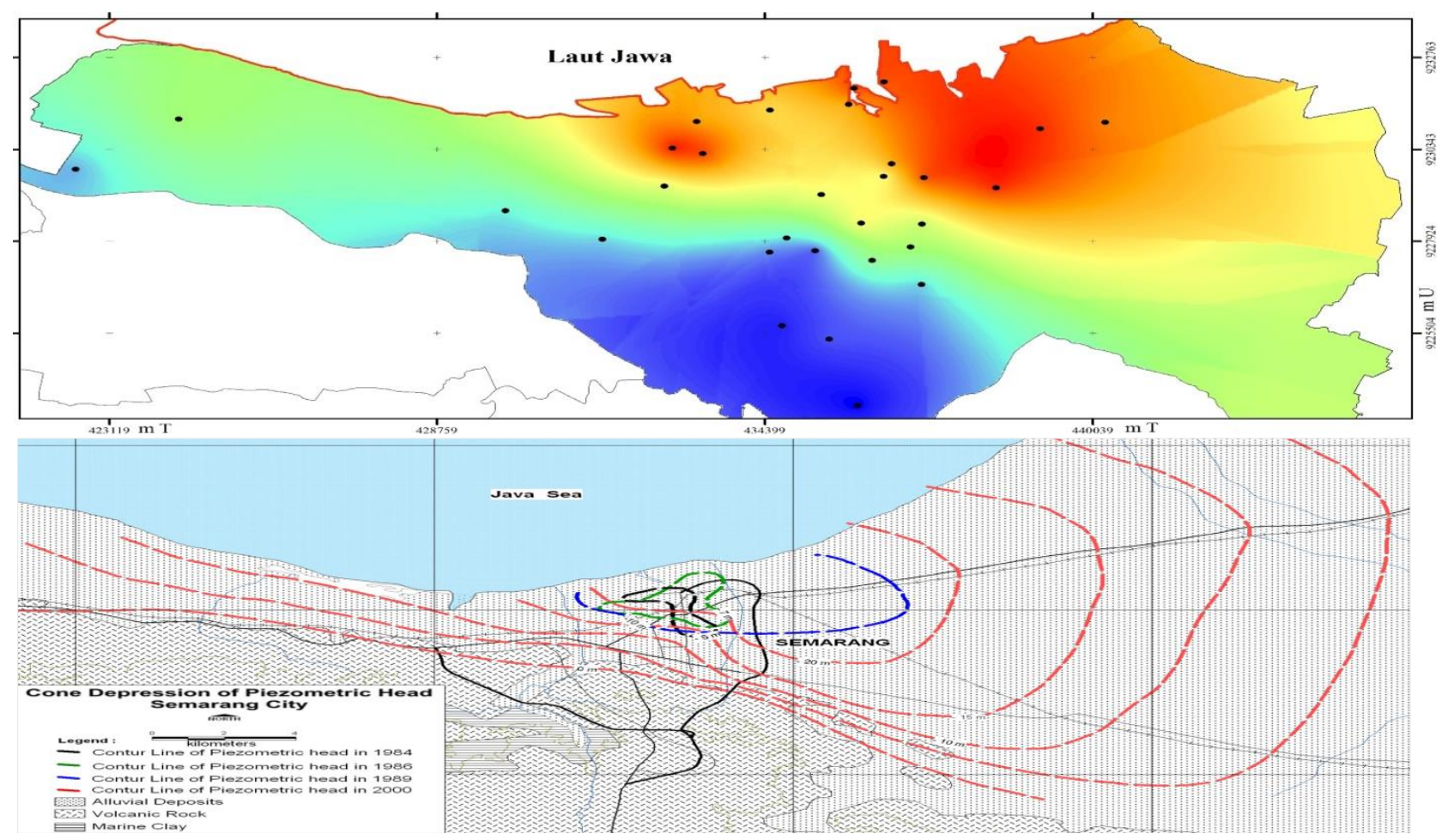

Fig.14. Maps correlation of land subsidence and water table decline in Semarang city. Generally we can see area where large subsidence existed correspond to significant declining of water table in confine aquifer.

There are several recognized causes such as natural compaction, loading of building, compaction of aquifer due to exploitation of groundwater, compaction of oil and gas reservoir due the exploitation and tectonic influence the subsidence. Many of publication conclude that the over exploitation of groundwater plays an important role on the subsidence (Holjer and Thomas [17], Rajiyowiryono [18], JICA [19]) and for the Semarang case it probably the same. Figure 14 and 15 each shows maps and graphs correlation of land subsidence and water table decline on the deep confine aquifer around Semarang city.

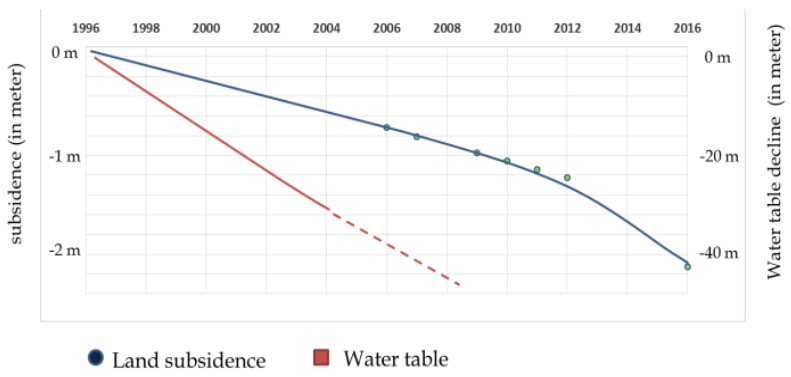

Fig.15. Graphs correlation of land subsidence and water table decline in Semarang city.

It seems that the subsidence is continuing as the water table is continuing to decline. The declining is due to increasing need of water for people and factories. As we know that northern eastern of Semarang is industrial area. Coincidently this place is the largest of subsidence area.

\section{Conclusion}

Land subsidence is not a new phenomenon for Semarang city. The rate in the recent year in fact is considerably quite significant with trend of acceleration. The impact of land subsidence in Semarang are obviously there and can be seen in several forms, such as the wider expansion of (coastal) flooding areas "rob", cracking of buildings and infrastructure and increased inland sea water intrusion. It also badly influences the quality and amenity of the living environment and life (e.g. health and sanitation condition) in the affected areas. Adaptation and mitigation are considered very important. Sometime in the future if less action taken in adaptation and mitigation, ecological disaster would be more and more serious. The sinking of Semarang through the sea is not weak hypothesis indeed.

We noticed people increased their house, and the local government elevated the road and the bridge, etc. regularly over less decade period as part of adaptation. We also noticed the central government built the dyke and pumping station. Nevertheless the adaptation is only made temporally since significant land subsidence keep coming and worsening by the sea level which is keep rising. As for the mitigation, until now we have seen lack of mitigation program, monitoring or even ineffective mitigation (mangrove program) in Semarang related to this subsidence issue. Indeed we have big homework on dealing with the subsidence in Semarang city. We need to start thinking on better water management in the area. It is quite obvious that groundwater exploitation play an important role on the subsidence. We need to manage the exploitation. 
Simply if we show the Tokyo, Osaka, Shanghai cases, etc. where they successfully stop the groundwater exploitation, in other hand the land subsidence was also stopped. Off course it is not apple to apple comparison since subsurface properties are different, but from all the causes, we can only able to deal with the anthropogenic causes and that is the groundwater. We cannot stop the natural compaction and or even the tectonic if existed. It is worth to try on doing better water management.

As for last conclusion, monitoring is one very important thing on dealing with the land subsidence. How do we know that the land subsidence is accelerating or decreasing or stopping if none of monitoring is being taken?

\section{Acknowledgements}

Many thanks and appreciation to students from Institute of Technology Bandung and from Dipenogoro University who helped the investigation in the field, and especially to the local people in Semarang and nearby for kindly sharing the information and experience relating subsidence impacts

\section{References}

1. BPS, Website of the Badan Pusat Statistik (Statistics Indonesia), accessed date: 3 November 2011. http://www.bps.go.id/hasilSP2010/jateng/ (2011)

2. GRDC, Quaternary Geological Map of the Semarang Triangle, Jawa. Geological Research and Development Centre (GRDC), Bandung (1996)

3. Kuehn, F., Albiol, D., Cooksley, G., Duro, J., Granda, J., Haas, S., Hoffmann-Rothe, A and Murdohardono, D., Detection of land subsidence in Semarang, Indonesia, using stable point's network (SPN) technique. Environmental Earth Sciences, DOI 10.1007/s12665-009-0227-X (2009)

4. Lubis, A.M., Sato, T., Tomiyama, N., Isezaki, N and Yamanokuchi, T., Ground subsidence in Semarang-Indonesia investigated by ALOSPALSAR satellite SAR interferometry, Journal of Asian Earth Sciences, 40, 5, 30 March, pp. 10791088 (2011)

5. Abidin, H.Z., R. Djaja, H. Andreas, M. Gamal, K. Hirose, Y. Maruyama, Capabilities and Constraints of Geodetic Techniques for Monitoring Land Subsidence in the Urban Areas of Indonesia, Geomatics Research Australia. No.81, December, pp. 45-58 (2004)

6. Murdohardono, D., Sudradjat, G.M., Wirakusumah, A.D., Kuhn, F and Mulyasari, F., Land Subsidence Analysis through Remote Sensing and Implementation on Municipality Level; Case Study: Semarang Municipality, Central Java Province, Indonesia. Paper presented at the BGR-GAI-CCOP Workshop on Management of Georisks, 23-25 June, Yogyakarta (2009)
7. Kuehn, F., Albiol, D., Cooksley, G., Duro, J., Granda, J., Haas, S., Hoffmann-Rothe, A and Murdohardono, D., Detection of land subsidence in Semarang, Indonesia, using stable point's network (SPN) technique. Environmental Earth Sciences, DOI 10.1007/s12665-009-0227-x (2009)

8. Sukhyar, R., Status and Progress of Urban Geology in Indonesia. Atlas and Urban Geology Vol. 14 : The Ground Beneath Our Feet: a Factor in Urban Planning, United Nations ESCAP (Economic and Social Commission for Asia and the Pacific), New York, pp. 335 - 340 (2003)

9. Barry, T., The Soft Soils of Semarang. Paper presented at the Seminar and Workshop of Polder Systems in Waterfront Cities, 27-28 September, Jakarta (2001)

10. Van Bemmelen, The Geology of Indonesia. Vol. IA, Government Printing Office, Martinus Nijhof, The Netherlands (1949)

11. Marfai, M.A., Almohamad, H., Dey, S., Susanto, B and King, L., Coastal dynamic and shoreline mapping: multi-sources spatial data analysis in Semarang Indonesia. Environmental Monitoring and Assessment, 142, pp. 297-308 (2008)

12. Seeber, G., Satellite Geodesy: foundation, method, and applications, Walter de Gruyter, Berlin-New York, C7 (1993)

13. Abidin, H.Z., Penentuan Posisi dengan GPS dan Aplikasinya (PT. Pradnya Paramita, Jakarta, 1999)

14. Abidin, H.Z., Geodesi Satelit (Departemen Teknik Geodesi ITB, PT. Pradnya Paramita, Jakarta, 2001)

15. Hofmann-Wellenhof, B., Lichtenegger, H. and Walse, E., GNSS Global Navigation Satellite Systems: GPS, GLONASS, Galileo, and More. (Springer Verlag, Wien, 2007)

16. Beutler, G., H. Bock, E. Brockmann, R. Dach, P. Fridez, W. Gurtner, U. Hugentobler, D.Ineichen, J. Johnson, M. Meindl, L. Mervant, M. Rothacher, S. Schaer, T. Springer, R.Weber. Bernese GPS software version 4.2. , University of Berne, $515 \mathrm{pp}$ (2001)

17. Holzer and Thomas L., Land subsidence caused by groundwater withdrawal in Urban areas, GeoJournal 11.3 245-255. Reidel Publishing Company 1985 (1985)

18. Rajiyowiryono H., Groundwater and Land subsidence Monitoring along the North Coastal Plain of Java Island. CCOP Newsl 24(3):19 JulySeptember (1999)

19. JICA, Lesson learns from land subsidence in Tokyo Japan. Presentation on "high Level Meeting on Subsidence". Balai Kota DKI Jakarta Indonesia 2014 (2014) 